\title{
The role of the food and beverage department in enhancing overall hotel competitiveness in Malaysia
}

\begin{abstract}
The rising level of Malaysian incomes and the increase in tourism activities in recent years have generally enhanced the Malaysian hotel industry. The vast increase in the number of hotels in Malaysia is making the industry very competitive. Hotel restaurants help to create the overall ambience of the establishment via the decor, menu and services offered. Earlier researchers have reported that the understanding of customer expectation is a prerequisite for delivering superior services. This study was undertaken to examine the role of the hotelsô Food and Beverage $(\mathrm{F} \& \mathrm{~B})$ offerings in enhancing the overall hotel competitiveness in Malaysia via evaluating customer satisfaction levels towards the food, services, prices and the general environment created by the hotel F\&B outlet.
\end{abstract}

Keyword: Malaysian hotel industry; Hotel competitiveness; Customer satisfaction; Food and Beverage Department 